\title{
Jenis Tumbuhan Bertahan Hidup di Lahan Kering
}

\author{
Riri Yulianti Rusdi ${ }^{*}$ A.R Tolangara ${ }^{2}$ dan Hasna Ahmad ${ }^{3}$ \\ 1, 2,3 Program Studi Pendidikan Biologi Universitas Khairun \\ *Corresponding authors: riri.yulianti.ry@gmail.com \\ Manuscript received: 12-06-2017 Revision accepted: 20-08-2017
}

\begin{abstract}
Abstrak
Air merupakan bagian terbesar penyusun jaringan tumbuh-tumbuhan. Air berfungsi mengatur setiap proses metabolisme tanaman secara langsung atau tidak langsung. Air yang tersedia di dalam tanah berada pada kapasitas lapang. Air pada kapasitas lapang adalah air yang tetap tersimpan dalam tanah. Air dapat hilang dalam bentuk uap air dari jaringan hidup tanaman yang terletak di atas permukaan tanah, air tersebut daapt hilang melewati stomata, kutikula, dan lentisel disebut transpirasi. Air pun dapat hilang akibatnya tanah menjadi kering. Apabila tanaman hidup dalam kondisi ini, maka tanaman akan mengalami cekaman air (Water stress) dan akhirnya mati. Penelitian ini bertujuan untuk mengetahui jenis tumbuhan yang mampu bertahan hidup di lahan kering beserta lamanya waktu tanaman dalam bertahan hidup. Penelitian ini bersifat eksperimen yang menggunakan Rancangan Acak Lengkap (RAL), dengan 4 perlakuan dan 5 kali ulangan. Pemberian air sekali dalam 9 bulan dan pengamatan dilakukan seminggu sekali dengan parameter tinggi tanaman dan jumlah daun. Sedangkan untuk faktor lingkungan berupa $\mathrm{pH}$, suhu dan kelembaban tanah diukur pada awal penelitian dan akhir penelitian. Kemudian data tersebut dianalisis menggunakan uji Koefisien Variasi $(\mathrm{KV})$. Hasil penelitian menunjukkan bahwa jenis tanaman yang mampu bertahan hidup di lahan kering adalah jagung dengan waktu 20 minggu (5 bulan).
\end{abstract}

Kata Kunci : Jenis Tumbuhan, bertahan hidup, lahan kering

\begin{abstract}
Water is the biggest constituent of plant tissues. Water serves to regulate all plant metabolism processes, directly or indirectly. Water available in the soil is in field capacity, which is water that is kept in the soil. The water can be lost in form of vapor from plant living tissues located on the soil surface. The water can be lost through stomata, cuticle and lenticel and it is called transpiration. The loss of water causes soil to dry. If plant lives in this condition, the plant will experience water stress and eventually it will die. The research aimed to find out the type of plant that able to survive on dry land and the duration of the survival. The research was an experimental research using a completely randomized design (RAL) with four treatments and 5 repetitions. Watering was conducted once in 9 months and observation was conducted once in a week with parameters of plant height and number of leaves. Regarding the environmental factors, namely, $\mathrm{pH}$, temperature and, soil humidity, they were measured in the beginning and end of the research. Data was analyzed using variance coefficient (KV) test. The research result indicated that type of plant that survived on dry land was corn with 20 weeks (5 months) of period.
\end{abstract}

Keywords: Type of plant, survival, dry land 
TECHNO: Vol. 06 ( 02): 09-14 Oktober 2017

\section{PENDAHULUAN}

Air merupakan bagian terbesar penyusun jaringan tumbuh-tumbuhan. Unsur hara dalam tanah yang diperlukan tanaman harus dilarutkan dalam air sebelum dapat diserap oleh akar tanaman yang selanjutnya diangkut ke seluruh bagian tanaman. Air diperlukan dalam proses asimilasi dan sebagai pengatur setiap proses metabolisme tanaman secara langsung atau tidak langsung yang dipengaruhi oleh ketersediaan air (Kramer, 1980). Kebutuhan air bagi tumbuhan berbeda-beda, tergantung jenis tumbuhan dan fase pertumbuhannya. Pada musim kemarau, tumbuhan sering mendapatkan cekaman air (water stress) karena kekurangan pasokan air di daerah perakaran dan laju evapotranspirasi yang melebihi laju absorbsi air oleh tumbuhan (Solichatun dkk, 2005).

Tubuh tanah merupakan medium tempat tumbuhnya tanaman sehingga tanaman dapat tumbuh tegak dan kokoh, sebagai wadah dan sumber unsur hara dan air, dan sebagai pengendali keadaan-keadaan lain yang diperlukan untuk menunjang pertumbuhan tanaman. (Mas'ud,1992). Lahan kering umumnya terdapat di dataran tinggi (daerah pegunungan) yang ditandai dengan topografinya yang bergelombang dan merupakan daerah penerima dan peresap air hujan yang kemudian dialirkan ke dataran rendah, baik melalui permukaan tanah (sungai) maupun melalui jaringan air tanah. Jadi lahan kering didefinisikan sebagai dataran tinggi yang lahan pertaniannya lebih banyak menguntungkan Lahan kering diterjemahkan dari kata "upland" yang menunjukkan kepada gambaran "daerah atas". (Moore, 1977; Monkhouse \& Small, 1978 dalam Saleh, 2004).

Lahan kering biasanya berkualitas rendah dan sebagian besar terdiri dari tanah podsolik merah kuning, maka dapat dipastikan bahwa akan terjadi defisiensi unsur-unsur hara (Fe, Bo, $\mathrm{Mn}, \mathrm{Cu}, \mathrm{Zn}, \mathrm{Cl})$. Biasanya pada tanah podsolik merah kuning kandungan bahan organik di horison A kurang dari 10 persen dan kandungan unsur hara N, P, K dan Ca biasanya rendah, reaksi tanah sangat masam hingga masam $(\mathrm{pH} \mathrm{3,5-5,5).} \mathrm{Permeabilitas} \mathrm{sedang} \mathrm{hingga} \mathrm{agak}$ lambat, daya menahan air kurang dan peka terhadap erosi, produktivitas tanah ini rendah sampai sedang. (Soewardi, 1985 dalam Saleh, 2004).

Rumput menunjukkan kisaran toleransi yang luas, terutama dalam hubungannya dengan tipe-tipe dan kondisi-kondisi tanah. Reaksi terhadap berbagai macam kondisi dinyatakan dalam perkembangan akar, unsur-unsur hara dan keadaan air. Rumput tidak mengikat nitrogen, tetapi tergantung dalam dan luasnya sistem perakaran, dan jangka panjang menampung membantu menghasilkan bahan organik dalam jumlah yang banyak. Rumputrumput tidak memperbaiki tanah yang hilang oleh erosi, tetapi sifat fisiknya, terutama bila terjadi penutupan yang lebat, membantu mengurangi pencucian hara (leaching), menahan butir debu yang dibawa dari tempat lain dan mengurangi hempasan air hujan pada permukaan tanah. Rumput-rumput berperan penting untuk pengawetan tanah (Mcilroy, 1976).

Tanaman jagung merupakan salah satu jenis tanaman pangan biji-bijian. Jagung termasuk tanaman yang tidak memerlukan persyaratan khusus dalam penanamannya. Hal ini disebabkan karena varietas jagung biasa memiliki sifat-sifat genetis dengan keragaman yang lebih luas dan lebih unggul, sehingga mampu berada-ptasi dengan kondisi lingkungannya. Sifat-sifat genetis ini pula yang mempengaruhi ketahanannya terhadap faktor lingkungan-nya 
(Abdelmoneim, 2014 dalam Teguh dkk 2012). Rumput dapat dikatakan sebagai salah satu tumbuh-tumbuhan darat yang paling berhasil bertahan hidup dan terdapat dalam semua tipe habitat dan berada pada bermacam-macam keadaan. Bentuk kehidupannya bervariasi dari yang berumur pendek sampai tumbuh-tumbuhan berumur panjang yang akan tumbuh tergantung pada keadaan tempat tumbuhnya (Mcilroy, 1976).

Dari latar belakang di atas maka masalah dalam penelitian ini yaitu jenis tumbuhan apa yang mampu bertahan hidup di lahan kering, dan berapa lama waktu yang diperlukan jenis tumbuhan tersebut untuk tumbuh pada lahan kering.

Tujuan penelitian adalah untuk mengetahui jenis tumbuhan yang mampu bertahan hidup di lahan kering, untuk mengetahui waktu yang diperlukan tiap jenis tumbuhan yang mampu tumbuh pada lahan kering.

\section{METODE PENELITIAN}

Penelitian ini menggunakan Rancangan Acak Lengkap (RAL) yang terdiri dari 4 perlakuan yaitu tanah (kering) ditanami jenis alang-alang, rumput teki, rumput jelai, dan jagung sebagai kontrol. Jumlah perlakuan seluruhnya ada 4 dengan 5 ulangan. Pada penyiraman menggunakan air sebanyak $500 \mathrm{ml} /$ polybag. Setelah itu, tanaman dibiarkan selama 9 bulan tanpa dilakukan penyiraman. Pengamatan dilakukan seminggu sekali selama 9 bulan, dilakukan pengukuran pertumbuhan yang meliputi tinggi tanaman, dan jumlah daun serta pengukuran suhu, $\mathrm{pH}$, dan kelembaban tanah Analisis data menggunakan rumus koefisien variasi.

\section{HASIL PENELITIAN}

Berdasarkan hasil penelitian dengan parameter berupa tinggi tanaman dan jumlah daun, kemudian data tersebut dianalisis dengan menggunakan Koefisein Variasi yang hasilnya disajikan pada Tabel 1 .

Tabel 1. Hasil uji Koefisien Variasi (KV) pada Tinggi Tanaman

\begin{tabular}{clccc}
\hline No & \multicolumn{1}{c}{ Jenis Tanaman } & Rerata & Standar Deviasi & KV \% \\
\hline 1 & Jagung (Co) & 113.55 & 52.96 & 46.64 \\
2 & Rumput Jelai (J) & 53.14 & 32.97 & 62.04 \\
3 & Rumput Teki (T) & 16.93 & 8.28 & 48.85 \\
4 & Alang-Alang (A) & 14.78 & 9.63 & 65.21 \\
\hline
\end{tabular}

Koefisien Variasi (KV) menyatakan bahwa nilai KV yang paling terendah adalah yang paling baik. Dari tabel 1 di atas menunjukkan bahwa jenis tanaman yang tumbuh baik di lahan kering yaitu jagung dengan nilai $\mathrm{KV}=46.64 \%$ dalam waktu 20 minggu ( 5 bulan), kemudian disusul rumput teki dengan nilai $\mathrm{KV}=48.85 \%$ dalam waktu $19 \mathrm{minggu}$, rumput jelai dengan nilai $\mathrm{KV}=62.04 \%$ dalam waktu $19 \mathrm{minggu}$, dan yang terakhir adalah alang-alang dengan nilai $\mathrm{KV}=65.21 \%$ dalam waktu 15 minggu. Dari keempat jenis tanaman ini bila dibandingkan maka tanaman yang paling baik tumbuh di lahan kering adalah tanaman jagung. Berikut adalah hasil uji Koefisien Variasi pada jumlah daun disajikan pada Tabel 2 
TECHNO: Vol. 06 ( 02): 09-14 Oktober 2017

Tabel 2. Hasil uji Koefisien Variasi pada Jumlah Daun

\begin{tabular}{clccc}
\hline No & Jenis Tanaman & Rerata & Standar Deviasi & KV \% \\
\hline 1 & Jagung (Co) & 5.40 & 2.56 & 47.38 \\
2 & Rumput Jelai (J) & 24.30 & 18.71 & 77.01 \\
3 & Rumput Teki & 17.62 & 9.76 & 55.38 \\
4 & Alang-Alang & 0.39 & 0.30 & 77.10 \\
\hline
\end{tabular}

Koefisien Variasi (KV) menyatakan bahwa nilai KV yang paling terendah merupakan hasil yang paling baik. Dari tabel 2 di atas menunjukkan bahwa jenis tanaman yang tumbuh baik di lahan kering yaitu jagung dengan nilai $\mathrm{KV}=47.38 \%$ dalam waktu 20 minggu, kemudian disusul rumput teki dengan nilai KV 55.38\% dalam waktu 19 minggu, rumput jelai dengan nilai $\mathrm{KV}=77.01 \%$ dalam waktu $19 \mathrm{minggu}$, dan yang terakhir adalah alang-alang dengan nilai $\mathrm{KV}=77.10 \%$ selama 15 minggu. Dari keempat jenis tanaman ini bila dibandingkan maka tanaman yang paling baik tumbuh di lahan kering adalah tanaman jagung. Ini berarti tanaman jagung merupakan tanaman yang memiliki nilai KV paling baik dalam pertumbuhan tinggi tanaman dan jumlah daun.

Berdasarkan hasil penelitian ditemukan bahwa tumbuhan yang dapat bertahan hidup di lahan kering adalah tanaman jagung, dimana jumlah daun dan tinggi tanaman lebih baik dibandingkan tanaman lain. Tinggi tanaman merupakan ukuran tanaman yang selalu diamati sebagai indikator pertumbuhan serta sebagai parameter untuk menilai pengaruh lingkungan atau perlakuan yang diterapkan terhadap tanaman karena tinggi tanaman merupakan ukuran pertumbuhan yang paling mudah diamati (Sitompul dan Guritno, 1995 dalam Ekowati dan Nasir, 2011).

Tinggi tanaman mempengaruhi jumlah daun, semakin tinggi tanaman, maka makin banyak jumlah daun. Jumlah daun akan bertambah seiring dengan pertambahan umur tanaman. Tinggi tanaman menyebabkan pertambahan ruas batang dan daun, sehingga mempengaruhi jumlah daun (Ridho dkk, 2014). Daun merupakan organ tanaman yang dapat melakukan proses fotosintesa, Jumlah daun yang banyak akan mempengaruhi besarnya proses fotosintesis (Krenatita, 2013). Pengamatan terhadap jumlah daun sangat diperlukan, karena selain sebagai indikator pertumbuhan, jumlah daun juga diperlukan sebagai data penunjang untuk menjelaskan proses pertumbuhan yang terjadi pada tumbuhan (Ekowati dan Nasir, 2011).

Hasil uji kofisien variasi (KV) tinggi tanaman jagung dan jumlah daun memiliki nilai yang paling baik dibandingkan dengan rumput teki, rumput jelai, dan alang-alang dengan kata lain, jagung merupakan tanaman yang paling baik di lahan kering. Jagung memiliki pertumbuhan tinggi tanaman yang besar dan jumlah daun yang banyak serta permukaan daunnya luas. Jagung merupakan tanaman serealia yang paling produktif di dunia, sehingga cocok ditanam di wilayah bersuhu tinggi, dan pematangan tongkol ditentukan oleh akumulasi panas yang diperoleh tanaman. Jagung mempunyai daya adaptasi yang tinggi, dapat tumbuh pada berbagai jenis tanah dan ketinggian tempat. Jagung merupakan tanaman C4 yang sangat efisien dalam pemanfaatan radiasi matahari. Selain itu, selama 5 bulan tanaman jagung tumbuh dengan baik meskipun kekurangan air. Jagung biasa memiliki sifatsifat genetis dengan keragaman yang lebih luas dan lebih unggul, sehingga mampu 
beradaptasi dengan kondisi lingkungan yang ekstrim. Sifat-sifat genetis ini pula yang mempengaruhi ketahanannya terhadap faktor lingkungannya (Teguh dkk, 2012).

Jagung memiliki kandungan prolin yang pada saat mendapat cekaman, kandungan prolin akan meningkat. Prolin merupakan asam amino non esensial. Akumulasi prolin sebagai respon terhadap cekaman kekeringan telah dilaporkan pada beberapa tanaman. Prolin yang terakumulasi membantu sebagai sumber osmotikum sitoplasmik dan melindungi enzim sitoplasmik dan struktur seluler sehingga tanaman jagung mampu bertahan terhadap stress lingkungan (Kaswan dkk, 2011). Pada penelitian ini tanaman jagung mempunyai pH dari 6-7 sehingga cocok dengan pertumbuhannya. Tanaman jagung toleran terhadap reaksi keasaman tanah pada kisaran $\mathrm{pH} 5,5-7,0$. Tingkat keasaman tanah yang paling baik untuk tanaman jagung adalah pada $\mathrm{pH}$ 6,8. Hasil penelitian lain juga menunjukkan bahwa reaksi tanah berpengaruh terhadap hasil jagung. Reaksi tanah yang memberikan hasil tertinggi pada jagung adalah $\mathrm{pH}$ 6,8 (Rukmana, 1997).

Setelah 5 bulan hidup, tanaman jagung akhirnya mati. Kematian tanaman jagung diduga karena terdapat beberapa faktor. Pertama, kekurangan air yang berkepanjangan (kekeringan). Kekeringan yang terjadi pada tanaman merupakan salah satu masalah utama bagi pertumbuhan dan perkembangan suatu tanaman. Kekeringan dapat memberikan pengaruh yang cukup berarti dan dampaknya bisa menjadi permanen apabila tidak diatasi dengan segera. Araus et al (2002) dalam Effendi dkk (2016) menjelaskan bahwa kekeringan merupakan salah satu faktor utama yang membatasi pertumbuhan dan perkembangan tanaman.

Faktor yang kedua yaitu kekurangan unsur hara. Unsur hara yang merupakan zat makanan untuk tanaman. Kekurangan unsur hara ini terutama pada unsur hara makro $(\mathrm{C}, \mathrm{H}, \mathrm{O}, \mathrm{P}, \mathrm{K}$, $\mathrm{Mg}, \mathrm{N}$ ), salah satunya nitrogen. Nitrogen adalah unsur hara utama bagi pertumbuhan organorgan tanaman karena merupakan penyusun asam amino, amida dan nukleoprotein yang merupakan unsur penting bagi pembelahan sel (Erawati, 2010). Faktor ketiga yaitu umur tanaman jagung. Pada penelitian ini jagung hidup hingga 5 bulan dengan kata lain terdapat 150 hari jagung bertahan hidup. Jagung merupakan tanaman semusim (annual). Satu siklus hidupnya diselesaikan dalam 80-150 hari (Wirawan dan Wahab, 2007).

\section{KESIMPULAN}

Berdasarkan hasil dan pembahasan yang telah dikemukakan, maka dapat disimpulkan bahwa tumbuhan yang mampu bertahan hidup di lahan kering adalah jagung dengan waktu yang diperlukan untuk tumbuh di lahan kering yaitu 5 bulan atau 20 minggu.

\section{DAFTAR PUSTAKA}

Efendi, R. Aqil M. Takdir, A. Azrai M. 2016. Sidik Lintas dalam Penentuan Karakter Seleksi Jagung Toleran Cekaman Kekeringan (Online). http:// ejurnal.litbang.pertanian.go.id/index.php/IP/article/view/7212. Diakses 18 Juni 2017.

Ekowati D, Nasir M. 2011. Pertumbuhan Tanaman Jagung (zea mays l.) Varietas bisi-2 pada Pasir Reject dan Pasir Asli di Pantai Trisik Kulonprogo. Jurnal Manusia dan Lingkungan. Vol.3 ISSN 220 - 231. Diakses 10 Juni 2017.

Emanuael, B. 2003. Pengendalian Gulma di Perkebunan. Kanisius. Yogyakarta. 
Erawati. 2010. Identifikasi Gejala Kekurangan Unsur Hara pada Tanaman Jagung. BPTP. Nusa Tenggara Barat.

Kaswan Badami, Ahmad Amzeri. 2011. Identifikasi Varian Somaklonal Toleran Kekeringan pada Populasi Jagung Hasil Seleksi In Vitro PEG. Jurnal Agrovigor. Vol 4 (1) ISSN 19795777. Diakses, 8 Desember 2016.

Kramer, P.J. and T.T. Kozlowski, 1960. Physiology of Trees. Mc Graw-Hill Book Co. Inc. New York

Kresnatita, S. Koesriharti. Santoso, M. 2013. Pengaruh Rabuk Organik Terhadap Pertumbuhan Dan Hasil Tanaman Jagung Manis. Indonesian Green Technology Journal. Vol 2 ISSN 2338-1787. Diakses, 10 Juni 2017

Mas'ud, 1992. Telaah Kesuburan Tanah. Angkasa, Bandung

Mcilroy, R. 1976. Pengantar Budidaya Padang Rumput Tropika. Pradanya Paramita. Jakarta.

Saleh Eniza. 2004. Rencana Pemanfaatan Lahan Kering untuk Pengembangan Usaha Peternakan Ruminansia dan Usaha Tani Terpadu di Indonesia (Online). $\quad$ http:/ / repository.usu.ac.id/ bitstream/123456789/810/1/ternakeniza4.pdf. diakses pada 10 Desember 2016.

Rukmana, R. 1997. Usaha Tanaman Jagung. Kanisius. Yogyakarta.

Solichatun, Anggarwulan Endang, dan Mudyantini Widya. 2005. Pengaruh Ketersediaan Air. terhadap Pertumbuhan dan Kandungan Bahan Aktif Saponin Tanaman Ginseng Jawa (Talinum paniculatum Gaertn. Jurnal Biofarmasi.Vol 3 (2) (Hal 47-51) ISSN 1693-2242. Diakses, 9 Desember 2016.

Teguh Wijayanto, Sadimantara R. Sadimanta, E.Made. 2012. Respon Fase Pertumbuhan Beberapa Genotipe Jagung Lokal Sulawesi Tenggara Terhadap Kondisi Kekurangan Air. Jurnal Agroteknos Vol.2 (hal. 86-91) ISSN 2087-7706. Diakses, 1 November 2016

Wirawan, G.N. dan M.I. Wahab. 2007. Teknologi Budidaya Jagung. Diakses dari http:// www.pustaka-deptan.go.id. Tanggal 15 Juni 2017. 